\title{
Medicinal Plants Used by Raji Ethnic Tribe of Nepal in Treatment of Gastrointestinal Disorders
}

\author{
Lal Bahadur Thapa ${ }^{1 *}$, Til Maya Dhakal ${ }^{2}$, Raghunath Chaudhary ${ }^{1}$, Himanchal Thapa ${ }^{1}$ \\ ${ }^{1}$ Central Department of Botany, Tribhuvan University, Kirtipur, Kathmandu, Nepal \\ ${ }^{2}$ Siddha Nath Science Campus, Tribhuvan University, Mahendra Nagar, Kanchanpur, Nepal \\ *E-mail: lal_thapa25@yahoo.com
}

Received: 17.11.2013; Accepted: 22.12.2013

\begin{abstract}
A total of 43 plant species belonging to 40 genera and 29 families have been recorded as medicinal plants used traditionally by Raji people of Nepal for treatment of gastrointestinal disorders. Different parts of medicinal plants in different forms were reported to be used for treatment of 16 types of gastrointestinal disorders. The traditional healers and elderly people were well experienced in traditional method of using medicinal plants but they were worried about negligence of people towards such traditional use of valuable medicinal plants.
\end{abstract}

Key words: Ind igenous people, ethno-medic ine, traditional healing, Nepal

\section{Introduction}

Scientific research on medicinal plants used in indigenous medical system is needed for effective treatments of various kinds of diseases (Kadir et al., 2013). Gastrointestinal diseases are major causes of mortality in the world and among them infectious gastrointestinal diseases are becoming more complicated to treat due to drug resistance by infectious parasites (Culligan et al., 2009). Traditional medicines play important role in health care system in developing countries (Alves and Rosa, 2007). Developing countries can take extensive profit through study and applied research on local medicinal plants which are used traditionally against various diseases (Houghton, 1995). WHO Regional Committee for the South-East Asia Region accepted the vital role of traditional medicine in health care system in 2004 and meeting of WHO Executive Board in 2009 aimed to promote the potential of herbal medicines in national health system in the Region (WHO, 2009).

Indigenous and endangered Raji ethic people distributed in Mid Western and Far Western Nepal have strong knowledge and belief in traditional healing practices but now this knowledge is in danger of loss due to several factors such as change in life style, urbanization, ignorance of new generation and biodiversity loss (Maskey, 2007; Thapa, 2012). These factors are major causes of significant decrease in traditional knowledge on medicinal plants among various ethnic communities of Nepal.

Number of studies such as Enayet Hossain, 2007; Giday et al., 2009; Osawaru and Dania-Ogbe, 2010; Rout et al., 2010; Namsa et al., 2011 have documented valuable information on traditional use of medicinal plants. Also some studies (Moreno-Salazar et al., 2008; Dey and De, 
2012; Kadir et al., 2013) have been carried out particularly for gastrointestinal disorders. Some studies conducted among various ethnic tribes of Nepal (Bhattarai, 1991; Manandhar, 1991; Manandhar, 1998; Shrestha, 1998; Siwakoti and Siwakoti, 2000; Rai, 2004; Acharya and Pokhrel, 2006) have documented various medicinal plants used traditionally for treatment of various alignments. Study among endingered Raji indigenous people of Nepal, this research was carried out to explore and document the medicinal plants used by Raji traditional healers for the treatment of gastrointestinal disorders.

\section{Materials and methods Study area}

The study was carried out in Uttarganga, Chhinchu and Ghatgaun Village Development Committees (VDCs) of Surkhet district and two Village Development Committees (Chaumala and Khailad) of Kailali districts (Fig. 1). The Surkhet district lies between $28^{\circ} 40^{\prime} 26^{\prime \prime} \mathrm{N}$ and $81^{\circ} 35^{\prime} 20^{\prime \prime} \mathrm{E}$ is the original land of Rajis people. The population of Rajis in Uttarganga, Chhinchu and Ghatgaun VDCs is 50, 128 and 210, respectively. Kailali $\left(28^{\circ} 34^{\prime} \mathrm{N}\right.$ and $\left.80^{\circ} 34^{\prime} \mathrm{E}\right)$ is one of the most populous district by Raji. Raji population in Khailad VDC is 811 and in Chaumala VDC is 238 (Raji Salma Samaj, 2012).

\section{Data collection}

Current study was conducted from September 2012 to March 2013. The key informants (Raji traditional healers, knowledgeable and old aged persons) from selected 32 households were interviewed to get primary information on medicinal plants used in gastrointestinal disorders. Only those households were selected with the help of local informants from the VDCs where traditional healers, knowledgeable and old aged persons were available. A standard open ended semi-structured questionnaire was prepared for in-depth interview and verbal consent was obtained from the participants. Group discussion and informal meetings were also made. Plant collection for herbarium was made with key informants and knowledgeable people. The specimens were identified with the help of standard literature (Polunin and Stainton, 1984; Press et al., 2000; Manandhar, 2002) and by comparing with specimens at Tribhuvan University Central Herbarium $(\mathrm{TUCH})$. The herbarium specimens are deposited in TUCH.

\section{Results \\ Taxonomic diversity and life form}

A total of 43 species of 40 genera and 29 families were recorded as medicinal plants used traditionally by indigenous Raji people of Nepal for treatment of gastrointestinal disorders. Out of them, 35 species belonged to 24 families of Dicot and 8 species to 5 families of Monocot. The larger families each having 3 species were Combretaceae, Euphorbiaceae, Fabaceae, and Zingiberaceae. Two species were recorded from each Asteraceae, Liliaceae, Menispermaceae, Moraceae, Myrtaceae and Rutaceae and rest 19 families were represented by single species. Among recorded medicinal plants, 20 species were trees followed by shrubs (10 species), herbs (9 species) and climbers (4 species) (Fig. 2) 
Lal Bahadur Thapa, Til Maya Dhakal, Raghunath Chaudhary, Himanchal Thapa / Our Nature (2013), 11(2): 177-186
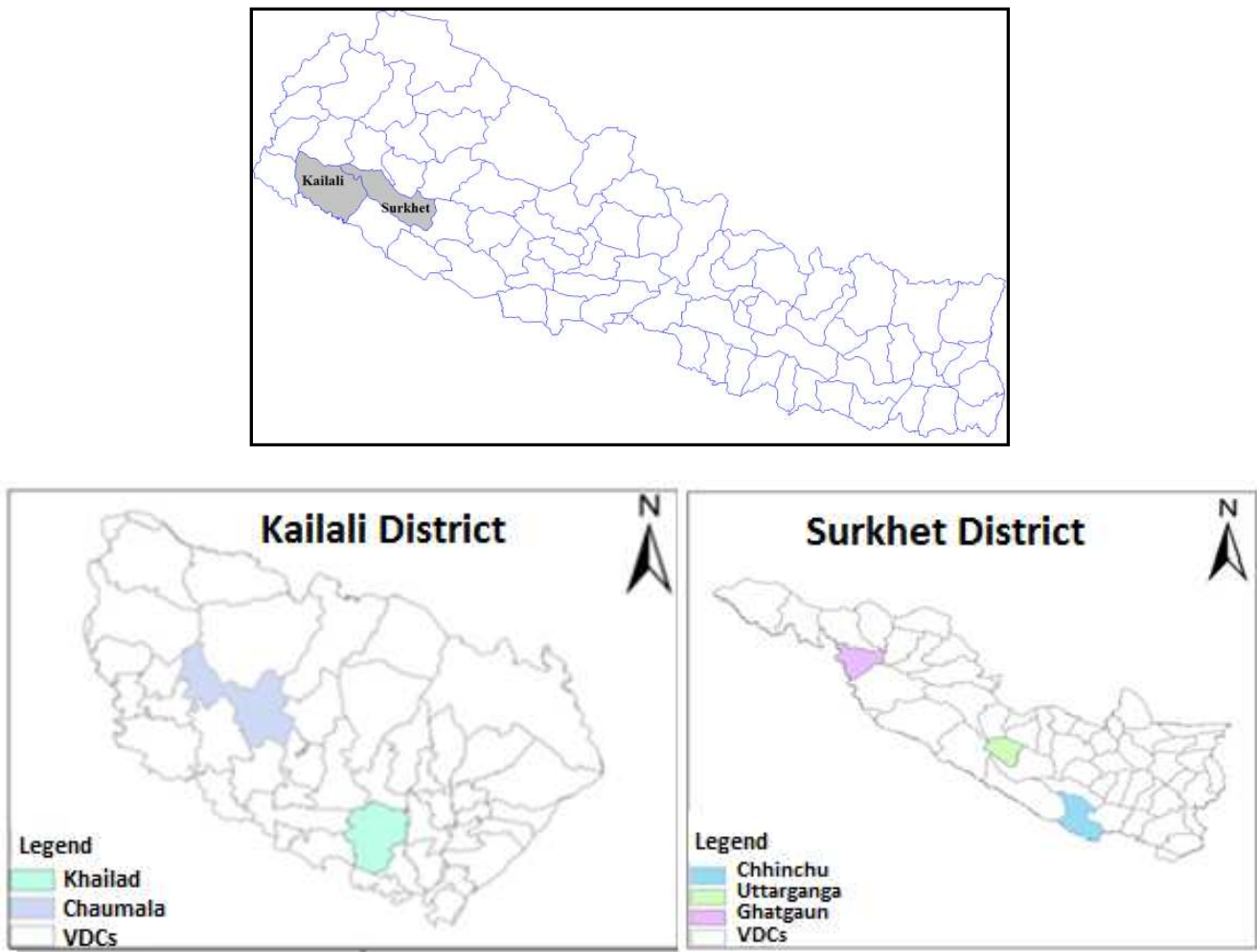

Chhinchu

Ghatgaun

VDCs

Figure 1. Study area, Surkhet and Kailali districts

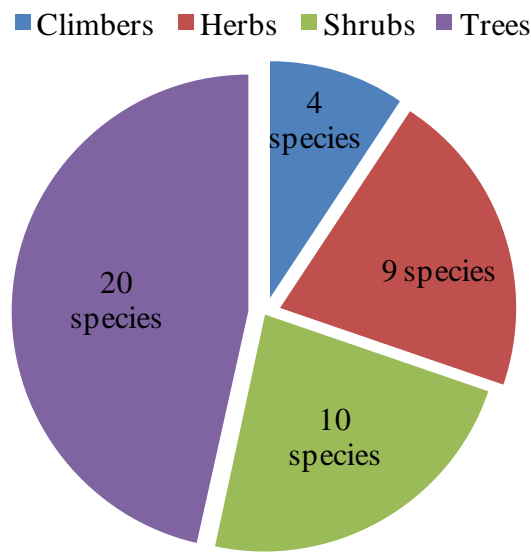

Figure 2. Life form (medicinal plants used by Rajis for gastrointestinal disorders) 


\section{Parts and forms used}

Different parts of medicinal plants in different forms were reported to be used for treatment of gastrointestional disorders in Raji community.

Bark was the most frequently used parts (17 species) followed by root (9 species); fruit (7 species); leaf (6 species); flower (4); rhizome ( 3 species); seed ( 2 species), whole plant (2 species), tuber (2 species) and sap (Sapium insigne (Royle) Benth. ex Hook. F. and Ficus recemosa L.) (Fig. 3). The major form of preparation of medicine was juice or extract (35 species) followed by paste and powder form (7 species), sap (2 species) and boiled tuber (Discorea bulbifera L.) (Fig. 4). The list of medicinal plants, parts and forms used is given in the table 1 .

\section{Gastrointestinal disorders}

The present study showed that 16 species of plants were used to treat diarrhea, 14 species for dysentery, 13 for stomach-ache, 8 for constipation, 6 for indigestion; bloody stool and gastric, 5 for loss of appetite, 4 for stomach and intestine ulcer and helminthes parasites, 3 for nausea or vomiting and 1 for the treatment of the tongue inflammation, cholera and green stool. Terminalia chebula and $T$. bellirica were two important species used in 6 types of gastrointestinal disorders such as gastric, constipation, indigestion, ulcer, vomiting, and diarrhea. Achyranthes aspera, Mirabilis jalapa, Curcuma zeodoaria and Hedychium spicatum were used for treatment of 5 types of disorders followed by Garuga pinnata, Cannabis sativa, Mallotus philippensis, Bauhinia variegata, Bauhinia vahlii, Aloe vera, Woodfordia fruticosa, Syzygium cumini, and Aegle marmelos used for 3 types of disorders. Twenty four species were used for less than 3 types of gastrointestinal disorders (Tab. 1).

\section{Discussion}

Raji is one of the endangered indigenous tribe of Nepal. They have not given up their tradition to collect mushrooms, tubers, wild edible and medicinal plants and other forest products. Traditional uses of medicinal plants can serve as the basic process to understand importance and phytochemical investigations (Dey and De, 2012). Rajis of Surkhet district have rich indigenous knowledge on medicine and they have practice to cure diseases by using different parts of plants (Maskey, 2007).

The larger families were Combretaceae, Euphorbiaceae, Fabaceae, and Zingiberaceae. Two species were recorded from each Asteraceae, Liliaceae, Menispermaceae, Moraceae, Myrtaceae and Rutaceae and rest 19 families were represented by single species. These fam-ilies are also reported by several researchers as the families having important species used commonly in traditional medicine system (Rahmatullah et al., 2010; Ayyanar and Ignacimuthu, 2011; Panda et al., 2011).

Trees and herbs are reported as frequently used medicinal plants for gastrointestinal disorders (Palombo, 2006; Kadir et al., 2013). Our study showed that most commonly used species for gastrointestinal disorders were trees followed by shrubs, herbs and climbers. Among the recorded medicinal plants, bark was the most frequently used parts followed by root; fruit; leaf; flower, rhizome; seed, whole plant, tuber and sap. Different parts of plants contain chemical compounds that work against bacteria, amoebae, fungi and nematods. The extract of various medicinal 
Lal Bahadur Thapa, Til Maya Dhakal, Raghunath Chaudhary, Himanchal Thapa / Our Nature (2013), 11(2): 177-186

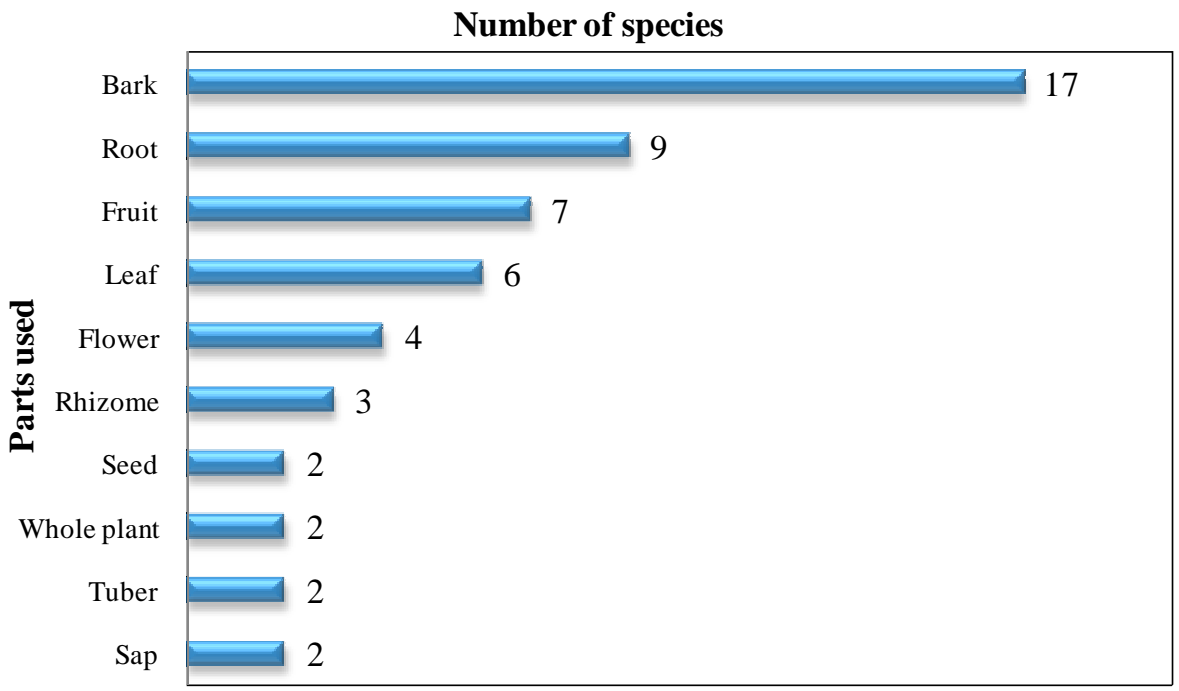

Figure 3. Parts used (medicinal plants used by Rajis for gastrointestinal disorders)

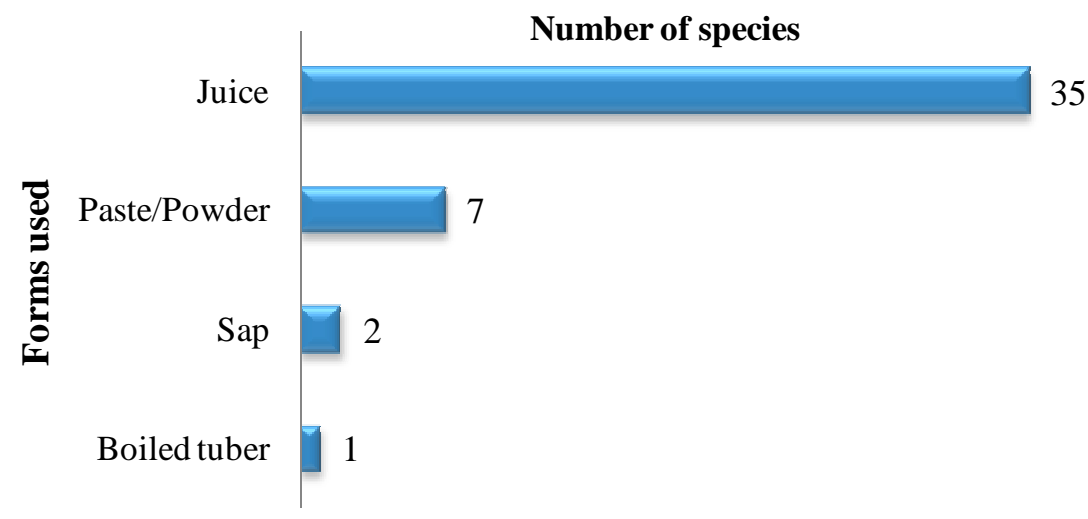

Figure 4. Forms used (medicinal plants used by Rajis for gastrointestinal disorders)

Table 1. Medicinal plants used for gastrointestinal disorders

\begin{tabular}{|c|c|c|c|c|c|}
\hline SN & Botanical names & Habit & Parts used & Diseases & Method and froms used \\
\hline \multicolumn{6}{|c|}{ Acanthaceae } \\
\hline 1 & $\begin{array}{l}\text { Justicia adhatoda } \mathrm{L} \text {. } \\
\text { Asuro }(\mathrm{N}) \text {, Asur }(\mathrm{R})\end{array}$ & Shrub & Root & Piles & $\begin{array}{l}\text { Root is crushed to extract } \\
\text { juice and taken orally }\end{array}$ \\
\hline \multicolumn{6}{|c|}{ Amaranthaceae } \\
\hline 2 & $\begin{array}{l}\text { Achyranthes aspera L. } \\
\text { Ulte Kuro (N), Chichibhata (R) }\end{array}$ & Herb & Root & $\begin{array}{l}\text { Gastric, na } \\
\text { of appetite } \\
\text { inflammatic }\end{array}$ & $\begin{array}{l}\text { Root is crushed and juice is } \\
\text { given orally, root paste is } \\
\text { applied in inflamed tongue }\end{array}$ \\
\hline
\end{tabular}

Anacardiaceae 
Lal Bahadur Thapa, Til Maya Dhakal, Raghunath Chaudhary, Himanchal Thapa / Our Nature (2013), 11(2): 177-186

3 Mangifera indica $\mathrm{L}$ Tree Bark $\quad$ Diarrhoea, dysentery Bark juice is extracted and Anp (N), Dang (R) given for treatment

\begin{tabular}{|c|c|c|c|c|c|}
\hline \multicolumn{6}{|c|}{ Arecaceae } \\
\hline 4 & $\begin{array}{l}\text { Phoenix acaulis } \\
\text { Buch.-Ham } \\
\text { Khajuri (N/R) }\end{array}$ & Roxb.exShrub & Stem, fruit & Stomach problem & $\begin{array}{l}\text { Inner part of stem or fruit is } \\
\text { eaten as medicine for } \\
\text { stomach problem }\end{array}$ \\
\hline & epiadaceae & & & & \\
\hline 5 & $\begin{array}{l}\text { Calotropis gigantea } \\
\text { Dryand. } \\
\text { Ank }(\mathrm{N}) \text {, Madar }(\mathrm{R})\end{array}$ & (L.) Shrub & Bark & Bloody stool & $\begin{array}{l}\text { Bark juice extracted and } \\
\text { given for treatment }\end{array}$ \\
\hline
\end{tabular}

\section{Asteraceae}

6 Spilanthes calva DC Marethi (N), Biks (R)

Herb Flower $\quad$ Stomach disorder

Inflorescence is eaten raw Artemisia vulgaris $\mathrm{L}$.

Shrub Root or juice is extracted

$7 \quad$ Artemisia vulgaris $\mathrm{L}$. Antihelminthic Root and leaf Juice is erberidaceae

8 Berberis aristata DC. Shrub Bark Diarrhea $\quad$ Bark juice is extracted and Chutro $(\mathrm{N})$, Trikhula $(\mathrm{R})$ extracted and given orally

\section{Burseraceae}

9 Garuga pinnata Roxb. Dabdabe (N), Jyanda (R)

Cannabaceae

10 Cannabis sativa L. Shrub Leaf, seed Indigestion, Leaf juice or grinded seed Bhang $(\mathrm{N})$, Bhanga $(\mathrm{R})$

Combretaceae

11 Terminalia alata Heyne ex. Tree Roth

Saj (N), Sajha (R)

12 Terminalia chebula Retz Tree Bark, fruit Gastric, Bark juice is given orally, Harro $(\mathrm{N})$, Harain $(\mathrm{R})$ indigestion, ulcer, is prepared and mixed with vomiting, diarrhea Phyllanthus embellica

13 Terminalia bellirica (Gaertn.) Tree Bark, fruit Gastric, Bark juice is given orally, Roxb constipation, fruit is chewed and powder Barro (N), Barain (R) indigestion, ulcer, is prepared and mixed with vomiting, diarrhea Phyllanthus embellica

Dioscoreaceae

14 Dioscorea bulbifera L. Climber Tuber Antihelminthic Underground tubers or Githa $(\mathrm{N})$, Syak (R) bulbils are boiled and eaten to kill pinworms

\begin{tabular}{|c|c|c|c|c|}
\hline \multicolumn{5}{|c|}{ Dipterocarpaceae } \\
\hline 15 & $\begin{array}{l}\text { Shorea robusta Gaertn } \\
\text { Sal }(\mathrm{N}) \text {, Salahn }(\mathrm{R})\end{array}$ & Tree & Bark & $\begin{array}{l}\text { Bark juice is extracted and } \\
\text { given orally }\end{array}$ \\
\hline \multicolumn{5}{|c|}{ Ericaceae } \\
\hline 16 & $\begin{array}{l}\text { Rhododendron arboreun } \\
\text { Gurans (N/R) }\end{array}$ & Roxb. Tree & Bark, flower & $\begin{array}{l}\text { bloody Bark or flower juice is } \\
\text { given orally }\end{array}$ \\
\hline \multicolumn{5}{|c|}{ Euphorbiaceae } \\
\hline 17 & $\begin{array}{l}\text { Mallotus philippensis } \\
\text { Muell.-Arg. } \\
\text { Royani (N), Rugnang ( } \mathrm{R}\end{array}$ & (Larn.) Tree & Bark & $\begin{array}{l}\text { Diarrhea, dysentery, Bark Juice is extracted and } \\
\text { stomachache } \\
\text { given orally }\end{array}$ \\
\hline 18 & Phyllanthus urinaria $\mathrm{L}$. & Herb & Leaf & Diarrhoea, dysentery Leaf juice is given orally \\
\hline
\end{tabular}


Lal Bahadur Thapa, Til Maya Dhakal, Raghunath Chaudhary, Himanchal Thapa / Our Nature (2013), 11(2): 177-186

Bhui Amala (N), Jhar (R)

19 Sapium insigne (Royle) Benth. Tree Sap Cholera, green stool Sap is applied around navel ex Hook. F Khirro (N), Khiri (R) region for the treatment of cholera and green stool

Fabaceae

20 Bauhinia variegata $\mathrm{L}$. Tree Bark Diarrhea, dysentery, Bark is crushed and juice is Koiralo (N), Greainblack (R) bloody stool given orally

21 Acacia catechu (L.f.) Willd. Tree Bark, stem Stomachache The stem or bark is soaked Khayar (N), Khairang (R) in water and given orally

22 Bauhinia vahlii Wight \& Arn Climber Bark, seed Diarrhea, dysentery, Bark juice is given orally, Malu (N), Mee/Mrak (R) $\quad$ stomachache immature seed is also used

Liliaceae

23 Aloe vera (L.) Burn.f. Herb Leaf Constipation, Leaf juice is given orally Ghiu Kumari (N/R) stomachache, tonic

24 Asparagus racemosus Willd. Shrub Root stomach problems Root is crushed and juice is Kurilo (N), Kurila (R)

Lythraceae

25 Woodfordia fruticosa (L.) Kurz Tree Bark Diarrhea, Bark juice is extracted and Dhairo (N), Dhairee (R)

Malvaceae

26 Urena repanda Roxb. [Hort. Herb Root Diarrhea, dysentery Root extract is given Beng] Bamparag (R)

Menispermaceae

27 Tinospora cordifolia (Willd.) Climber Tuber Gastric, diarrhea Juice extracted from tuber Miers.

Gujar Gano (N), Bhrun (R)

28 Cissampelos pareira $\mathrm{L}$. Badalpate (N), Khalite (R)

Climber Whole plant Bloody stool, Plant is crushed to extract

Moraceae

29 Ficus recemosa $\mathrm{L}$ Tree Fruit $\quad$ Stomachache Dumri (N), Uvring (R)

30 Morus australis Poir. Kimbu (N), Toont (R)

Tree Root

Antihelminthic sticks paper over the affected part

Root is crushed and extracted juice is given orally to kill worms (Ascaris)

\begin{tabular}{|c|c|c|c|c|c|}
\hline \multicolumn{6}{|c|}{ Myricaceae } \\
\hline 31 & $\begin{array}{l}\text { Myrica esculenta Buch.-Ha } \\
\text { ex D.Don } \\
\text { Kafal (N), Kafla (R) }\end{array}$ & Tree & Bark & Diarrhea & $\begin{array}{l}\text { Bark juice is given orally } \\
\text { for treatment of stomach } \\
\text { disorders }\end{array}$ \\
\hline \multicolumn{6}{|c|}{ Myrtaceae } \\
\hline 32 & $\begin{array}{l}\text { Syzygium cumini (L.) Skeels } \\
\text { Jamun }(\mathrm{N}) \text {, Jamna (R) }\end{array}$ & Tree & Bark & $\begin{array}{l}\text { Diarrhea, dysentery } \\
\text { stomachache }\end{array}$ & $\begin{array}{l}\text { Bark Juice or immature } \\
\text { fruits are taken orally }\end{array}$ \\
\hline 33 & $\begin{array}{l}\text { Cleistocalyx operculatus } \\
\text { (Roxb.) Merr. \& Perry } \\
\text { Kyamuna (N), Bhukijabu (R) }\end{array}$ & Tree & Fruit & Diarrhea, dysentery & $\begin{array}{l}\text { Edible fruit is beneficial for } \\
\text { diarrhea and dysentery }\end{array}$ \\
\hline \multicolumn{6}{|c|}{ Nyctaginaceae } \\
\hline 34 & $\begin{array}{l}\text { Mirabilis jalapa L. } \\
\text { Malati }(\mathrm{N}) \text {, Lankafool }(\mathrm{R})\end{array}$ & $\begin{array}{l}\text { Sub- } \\
\text { Shrub }\end{array}$ & Root & $\begin{array}{l}\text { Gastric, ulcer } \\
\text { stomachache, }\end{array}$ & $\begin{array}{l}\text { Juice extracted from root is } \\
\text { taken orally, root can be }\end{array}$ \\
\hline
\end{tabular}


Lal Bahadur Thapa, Til Maya Dhakal, Raghunath Chaudhary, Himanchal Thapa / Our Nature (2013), 11(2): 177-186

\begin{tabular}{|c|c|c|c|c|c|}
\hline \multicolumn{4}{|c|}{ 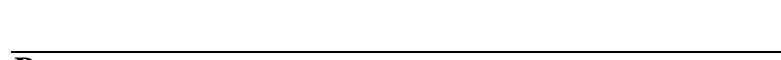 } & \multicolumn{2}{|c|}{ constipation $\quad$ dried and stored } \\
\hline \multicolumn{6}{|c|}{ Poaceae } \\
\hline 35 & $\begin{array}{l}\text { Imperata cylindrica (L.) } \\
\text { Beauv } \\
\text { Siru (N), Sirau (R) }\end{array}$ & P. Grass & Root & Antihelminthic & $\begin{array}{l}\text { Root juice is extracted in } \\
\text { half a glass of water and } \\
\text { give two times a day for } \\
\text { Ascariasis }\end{array}$ \\
\hline \multicolumn{6}{|c|}{ Rosaceae } \\
\hline 36 & $\begin{array}{l}\text { Rosa sp. } \\
\text { Gulab (N), Gulabi (R) }\end{array}$ & Shrub & Flower & Dysentery & $\begin{array}{l}\text { Extracted juice of flower is } \\
\text { given orally }\end{array}$ \\
\hline \multicolumn{6}{|c|}{ Rutaceae } \\
\hline 37 & $\begin{array}{l}\text { Zanthoxylum armatum DC. } \\
\text { Timur }(\mathrm{N}) \text {, Timru }(\mathrm{R})\end{array}$ & Tree & Fruit & Diarrhea & $\begin{array}{l}\text { Fruits are boiled and juice } \\
\text { is taken orally. }\end{array}$ \\
\hline 38 & $\begin{array}{l}\text { Aegle marmelos }(\mathrm{L} .) \text { Corr. } \\
\operatorname{Bel}(\mathrm{N}) \text {, Belang/Bela }(\mathrm{R})\end{array}$ & Tree & Leaf, fruit & $\begin{array}{l}\text { Gastric, ulcer } \\
\text { constipation, piles }\end{array}$ & $\begin{array}{l}\text { er, Leaf extract or ripe fruit is } \\
\text { eaten }\end{array}$ \\
\hline \multicolumn{6}{|c|}{ Sapotaceae } \\
\hline 39 & $\begin{array}{l}\text { Diploknema butyracea (Roxb. } \\
\text { H.J.Lam } \\
\text { Chiuri (N), Chiure (R) }\end{array}$ & o.) Tree & Bark & Diarrhea, dysentery & $\begin{array}{l}\text { Bark juice is effective for } \\
\text { diarrhea and dysentery }\end{array}$ \\
\hline \multicolumn{6}{|c|}{ Umbelliferae } \\
\hline 40 & $\begin{array}{l}\text { Centella asiatica }(\mathrm{L} .) \text { Urban } \\
\text { Ghodtapre }(\mathrm{N}), \text { Ghodthapa }(\mathrm{R})\end{array}$ & Herb & Whole plant & $\begin{array}{l}\text { Indigestion, loss o } \\
\text { appetite }\end{array}$ & $\begin{array}{l}\text { of Whole plant is crushed and } \\
\text { its juice is taken orally }\end{array}$ \\
\hline \multicolumn{6}{|c|}{ Zingiberaceae } \\
\hline 41 & $\begin{array}{l}\text { Zingiber officinale Rosc. } \\
\text { Aduwa }(\mathrm{N}) \text {, Adang }(\mathrm{R})\end{array}$ & Herb & Rhizome & $\begin{array}{l}\text { Indigestion, loss o } \\
\text { appetite, } \\
\text { constipation }\end{array}$ & $\begin{array}{l}\text { of Rhizome piece is chewed } \\
\text { or put in tea or used in } \\
\text { powder form }\end{array}$ \\
\hline 42 & $\begin{array}{l}\text { Curcuma zeodaria Rosc. } \\
\text { Kachur (N/R) }\end{array}$ & Herb & Rhizome & $\begin{array}{l}\text { Indigestion, loss o } \\
\text { appetite, } \\
\text { constipation, } \\
\text { stomachache }\end{array}$ & $\begin{array}{l}\text { of Rhizome piece is chewed, } \\
\text { rhizome is crushed and } \\
\text { paste is eaten with ghee } \\
\text { and honey }\end{array}$ \\
\hline 43 & $\begin{array}{l}\text { Hedychium spicatum } \mathrm{Sm} \\
\text { Gaz Kachur (N/R) }\end{array}$ & Herb & Rhizome & $\begin{array}{l}\text { Indigestion, loss o } \\
\text { appetite, } \\
\text { constipation, } \\
\text { stomachache }\end{array}$ & $\begin{array}{l}\text { of Rhizome piece is chewed, } \\
\text { rhizome is crushed and } \\
\text { paste is eaten with ghee } \\
\text { and honey }\end{array}$ \\
\hline
\end{tabular}

$\mathrm{N}=$ Nepali Name, $\mathrm{R}=$ Raji Name

plants used by traditional healers have antibacterial, anti-amoebic, antidiarrhoeic and antihelminthic properties (Tona et al., 1998; McGaw et al., 2000; Taylor et al., 2001). The major mode of preparation of medicine was juice or extract (35 species) followed by paste and powder form (7 species), sap (2 species) and boiled tuber (Dioscorea bulbifera L.). The study found that there is practice to prepare fresh medicine in these forms and given orally for the treatment of gastrointestinal disorders.

\section{Conclusions}

The present study of the medicinal plants used for healing the gastrointestinal disorders revealed that Raji indigenous people of Nepal have good knowledge and practice based on their experiences and proved the potential to identify useful medicinal plants. The practitioners (traditional healers) and elderly people are well experienced but they are also worried about negligence of people on traditional uses of valuable medicinal plants. Therefore 
it is important that the traditional knowledge should be explored and documented properly for future uses. Additional analyses of biological activities and pharmacological tests are recommended for the further investigation.

\section{Acknowledgements}

The authors are grateful to University Grants Commission, Bhaktapur, Nepal for providing financial support and we are highly grateful to Raji Salm Samaj, Central Office, Tikapur for every support in our research and all Raji informants of both Surkhet and Kailali district who shared their valuable knowledge.

\section{References}

Acharya, A. and B. Pokhrel 2006. Ethno-medicinal plants used by Bantar of Bhaudaha, Morang, Nepal. Our Nature 4(1): 96-103.

Alves, R.R.N. and I.M.L. Rosa 2007. Biodiversity, traditional medicine and public health: where do they meet? Journal of Ethnobiology and Ethnomedicine 3: 14. doi: 10.1186/1746-4269-314

Ayyanar, M. and S. Ignacimuthu 1011. Ethnobotanical survey of medicinal plants commonly used by Kani tribals in Tirunelveli hills of Western Ghats, India. Journal of Ethnopharmacology 134(3): 851-864

Bhattarai, N.K. 1991. Folk herbal medicines of Makawanpurdistrict, Nepal. Int. Journal Pharmaconosy 29(4): 284-295

Culligan, E.P., C. Hill and R.D. Sleator 2009. Probiotics and gastrointestinal disease: success, problems and future prospects. Gut Pathogen 1: 9. doi:10.1186/1757-4749-1-19

Dey, A. and J.N. De 2012. Ethnobotanical survey of Purulia district, West Bengal, India for medicinal plants used against gastrointestinal disorders. Journa of Ethnobiology 143(1): 68-80.

Giday, M., Z. Asfaw, Z. Woldu and T. Teklehaymanot 2009. Medicinal plant knowledge of the Bench ethnic group of Ethiopia: an ethnobotanical investigation. Journal Ethnobiol Ethnomed 5: 34. doi: 10.1186/1746-4269-5-34
Houghton, P.J. 1995. The role of plants in traditional medicine and current therapy. The Journal of Alternative and Complementary Medicine 1(2): 131-143.

Kadir, M.F., M. Shahdaat, B. Sayeed and M.M.K. Mia 2013. Ethnopharmacological survey of medicinal plants used by traditional healers in Bangladesh for gastro intestinal disorders. Journal of Ethnopharmacology 147 (1): 148-156.

Manandhar, N. 1998. Native phytotherapy among the Raute tribes of Dadeldhura district, Nepal. Journal of Ethnopharmacology 60(3): 199-206.

Manandhar, N.P. 1991. Medicinal plant lore of Tamang tribe of Kabhrepalanchwok district, Nepal. Economic Botany 45(1): 58-71

Manandhar, N.P. 2002. Plants and people of Nepal. Timber Press, Inc. Portland, Oregon, U.S.A.

Maskey, S. 2007. Indigenous knowledge system as resource for sustaining Raji work and life, A case study of Surkhet district. Social Inclusion Research Fund Secretariat, SNV Netherlands Development Organization, Kathmandu, Nepal.

McGaw, L.J., A.K. Jager and J. Van Staden 2000. Antibacterial, antihelminthic and antiamoebic activity in South African medicinal plants. Journal of Ethnobiology 72(1-2): 274-263.

Moreno-Salazar, S.F., R.E. Robles-Zepeda and D.E. Johnson 2008. Plant folk medicines for gastrointestinal disorders among the main tribes of Sonora, Mexico. Fitoterapia 79(2): 132-141.

Namsa, N.D., M. Mandal, S. Tangjang and S.C. Mandal 2011. Ethnobotany of the Manopa ethnic group at Arunachal Prades, India. Journal of Ethnobiol Ethnomed 7: 31. doi:10.1186/17464269-7-31

Osawaru, M.E. and F.M. Dania-Ogbe 2010. Ethnobotanical studies of West African Okra [Abelmoschus cailei (A. chev) Stevels] from some tribes of South Western Nigeria. Science World Journal 5(1): 36-41.

Palombo, E.A. 2006. Phytochemicals from traditional medicinal plants used in the treatment of diarrhea: Modes of action and effects on intestinal. Phytother. 20: 717-724.

Panda, S.K., S.D. Rout, N. Mishra and T. Panda 2011. Phytotherapy and traditional knowledge of tribal communities of Mayurbhanj district, Orissa, India. Journal of Pharmacognosy and Phytotherapy 3(7): 101-113.

Partha, P. and A.B.M. Enayet Hossain 2007. Ethnobotanical investigation into the Mandi ethnic 
Lal Bahadur Thapa, Til Maya Dhakal, Raghunath Chaudhary, Himanchal Thapa / Our Nature (2013), 11(2):

177-186

community in Bangladesh. Bangladesh Journal Plant Taxon 14(2): 129-145.

Polunin, O. and A. Stainton 1984. Flowers of Himalaya. Oxford, Oxford University Press.

Press, J.R., K.K. Shrestha and D.A. Sutton 2000. Annonated checklist of the flowering plants of Nepal. The Natural History Museum, London and Tribhuvan University, Kathmandu, Nepal. 430p.

Rahmatullah, M., M.E. Hasan, M.A. Is lam, F.I. Jahan, Syeda Seraj, A.R. Chowdhury, Farhana Jamal, M.S. Islam, Z.U.M.E.U. Miajee, Rownak Jahan and M.H. Ghowdhury 2010. A survey on medicinal plants used by the folk medicinal practitioners in three villages of Panchagarh and Thakurgaon district, Bangladesh. AmericanEurasian Journal of Sustainable Agriculture 4(3): 291-301.

Rai, S.K. 2004. Medicinal plants used by Meche people of Jhapa district, eastern Nepal. Our Nature 2(2):27-32

Raji Salma Samaj 2012. Raji Population Report. Report prepared by Raji Salma Samaj, Central Office, Tikapur, Kailali, Nepal. (Unpublished Report)

Rout, J., A.L. Sajem and M. Nath 2010. Traditional medicinal knowledge of Zeme (Naga) tribe of North Cachar Hills District, Assam on the treatment of Diarrhoea. Assam University Journal of Science and Technology 5: 163-169.

Shrestha, I. 1998. Ethnomedicobotanical studies of Gurung communities in Bichaur village, Lamjung, Nepal. Report, International Centre for Integrated Mountain Development, Kathmandu, Nepal. 70p.

Siwakoti, M. and S. Siwakoti 2000. Ethnomedicinal uses of plants among the Satar tribe of Nepal. In Ethnobotany and Medicinal Plants of Indian Subcontinent (Ed. J.K. Maheswari), Scientific publisher. pp. 98-108.

Taylor, J.L.S., T. Rabe, L.J. McGaw, A.K. Jager and J. van Staden 2001. Towards the scientific validation of traditional medicinal plants. Plant Growth Regulation 34(1): 23-37.

Thapa, L.B. 2012. Indigenous knowledge on common medicinal plants among Raji Community of Surkhet district, mid western Nepal. Nepalese Journal of Biosciences 2: 88-92.

Tona, L., K. Kambu, N. Ngimbi, K. Cimanga and A.J. Vlientinck 1998. Antiamoebic and phytochemical screening of some Congolese medicinal plants. Journal of Ethnobiology 61: 57-65.

WHO 2009. The use of herbal medicines in primary health care. Report of the Regional Meeting, 1012, March, 2009, Yangon, Myanmar. World Health Organization, Regional Office for South East Asia. 